\title{
GUILDS, EFFICIENCY, AND SOCIAL CAPITAL EVIDENCE FROM GERMAN PROTO-INDUSTRY
}

\author{
SHEILAGH OGILVIE
}

\author{
CESIFO WORKING PAPER NO. 820 \\ CATEGORY 10: EMPIRICAL AND TheORETICAL MethodS
}

DECEMBER 2002

\footnotetext{
An electronic version of the paper may be downloaded

- from the SSRN website: www.SSRN.com

- from the CESifo website: www.CESifo.de
} 


\title{
GUILDS, EFFICIENCY, AND SOCIAL CAPITAL: EVIDENCE FROM GERMAN PROTO-INDUSTRY
}

\begin{abstract}
This paper analyzes an early modern German economy to test alternative theories about guilds. It finds little evidence to support recent hypotheses arguing that guilds corrected market failures relating to product quality, training, and innovation. But it finds that guilds were social networks that generated a social capital of shared norms, common information, mutual sanctions, and collective political action. Guilds' social capital affected rival producers, suppliers, employees, consumers, the government, and the wider economy. Economic analyses of collective action, it is argued, can explain why guilds were so widespread while not necessarily being efficient.
\end{abstract}

JEL Classification: 010, N40, D7, D23, L4.

Keywords: guilds, social capital, social networks.

Sheilagh Ogilvie

Faculty of Economics

University of Cambrdige

Sidgwick Avenue

Cambridge CB3 9DD

United Kingdom

sco2@econ.cam.ac.uk 


\section{Introduction: Economic Models of Guilds}

Guilds were widespread in most European societies from the medieval period to - in some cases - the nineteenth century, and debate still rages about their economic effects. Some historians argue that guilds exercised costly monopolies, others that they were economically powerless, still others that they were positively beneficial. ${ }^{1}$ Political scientists and economists adduce guilds as exemplars of "social networks" which generated "social capital", thereby benefiting the economy at large. ${ }^{2}$ This paper tests alternative views of guilds by analysing their role in a German industrial region which was densely guilded into the nineteenth century, and which left rich local-level documentation.

A guild was an enduring corporate association, usually of practitioners of a particular occupation, which was legally endowed with the exclusive right to practise certain economic activities in a certain area by virtue of privileges granted by the political authorities. Although a small number of "religious guilds" (or "confraternities") engaged in devotional and charitable activities, and a few "political guilds" exercised urban administrative roles, the most common types were "craft guilds" and "merchant guilds" (also called "merchant companies" or "merchant associations").

"Craft guilds" were associations of master artisans in a particular branch of manufacturing; "merchant guilds" were associations of traders in a particular locality or a particular line of wares. Merchant guilds arose before craft guilds, but both were widespread in Europe by the twelfth century. Guilds of both sorts began to lose their powers in some parts of the Netherlands and England in the sixteenth century, but they survived in France and most parts of Germany, Italy, Scandinavia, and

\footnotetext{
${ }^{1}$ On this debate, see Ogilvie, State Corporatism, 308-10, 339-66; Pfister, "Craft Guilds", 12-14; Gustafsson, "Rise", 1-7, 12-13; Epstein, "Craft Guilds", 685-6; Reith, "Technische Innovation", 218.

${ }^{2}$ Putnam, Democracy, 163-85; Dasgupta, "Economic Progress", 351-2; Raiser, "Informal Institutions", 231.
} 
Iberia into the late eighteenth century. Some German territories did not abolish guilds until the later nineteenth century; Württemberg, for instance, retained its guilds until $18644^{3}$

Guilds are often portrayed as primarily medieval, urban, and craft-oriented. But this view is based on the experience of England and the Netherlands, which cannot be generalized. In most other parts of Europe, guilds existed not just in crafts but in export-oriented "proto-industries" and tertiary activities such as merchant trading. Rural or "regional" (rural-urban) guilds were formed in many central and southern European societies, including Germany, Switzerland, Austria, Bohemia, Italy, Spain, Greece, Bulgaria, and Serbia. And in many parts of Europe, guilds survived (indeed, continued being formed) into the eighteenth or even the nineteenth century. ${ }^{4}$ The range and importance of the economic sectors in which guilds operated, their existence in the countryside, and their survival to the dawn of industrialization and beyond, make it important to find out what they actually did.

The traditional literature on guilds consisted mainly of economic historians criticizing the cartelistic provisions of guild charters, and social historians praising guilds' contribution to the solidarity of pre-modern society. ${ }^{5}$ These two perspectives seldom intersected. Recently, however, there have been some notable efforts to rehabilitate guilds, on economic rather than socio-cultural grounds. This "rehabilitation" literature argues that guilds were efficient institutional arrangements that benefited the preindustrial economy. First, guilds are held to have solved asymmetries of information between producers, merchants and consumers concerning product quality, thereby increasing exchange and enabling industries to expand over larger spatial areas. ${ }^{6}$ Second, guilds are supposed to have overcome imperfections in markets for trained industrial labour, thereby improving

\footnotetext{
${ }^{3}$ Irsigler, "Zur Problematik", 54-5, 65; Ogilvie, State Corporatism, 72-9, 419-37; Pfister, "Craft Guilds", 12-14; Gustafsson, "Rise", 1-7, 12-13; Epstein, "Craft Guilds", 685-6.

${ }^{4}$ See Ogilvie, State Corporatism, 72-9, 419-37; Reininghaus, Gewerbe, 61-3, 71-2, 79-80; Pfister, "Craft Guilds", 11-14.

${ }^{5}$ For surveys of the debate, see Ogilvie, State Corporatism, 308-10, 339-66; Pfister, "Craft Guilds", 12-14; Gustafsson, "Rise”, 1-7, 12-13; Epstein, "Craft Guilds", 685-6; Reith, "Technische Innovation", 21-8.
} 
the performance of the pre-modern industrial sector. ${ }^{7}$ Third, guilds are regarded as having solved imperfections in markets for technological innovations, thereby contributing to preindustrial economic growth. ${ }^{8}$ Finally, guilds are portrayed as social networks that generated beneficial social capital by sustaining shared norms, punishing violators of these norms, effectively transmitting information, and successfully undertaking collective action. ${ }^{9}$

These arguments offer stimulating new perspectives on a widespread and important institution in the preindustrial economy. But up to now they have not been tested against alternative theories about guilds as institutions through deeper empirical analyses of particular industries and economies. The lack of thorough empirical studies is a serious gap, since guilds rarely restricted themselves to a single activity - maintaining quality, training labour, regulating technology, or undertaking collective political action. Instead, they engaged in a wide variety of interlinked economic, social, political, religious and cultural activities. To evaluate whether guilds were efficient institutions - or beneficial social networks - we must scrutinize the entire range of what they actually did in real-life situations. That is the purpose of this paper.

\section{The Württemberg Worsted Industry as a Test Case for Guilds}

To draw up a balance-sheet on the efficiency of a particular institution that engages in a

\footnotetext{
${ }^{6}$ Pfister, "Craft Guilds", 11, 14-18; Gustafsson, "Rise"; Reith, “Technische Innovation”, 49-53.

7 Epstein, "Craft Guilds", 688-93; Pfister, "Craft Guilds", 14, 18.

${ }^{8}$ Epstein, "Craft Guilds", 693-705; Reith, "Technische Innovation”, 45-8.

9 Putnam, Democracy, 163-85; Dasgupta, "Economic Progress", 351-2; Raiser, "Informal Institutions", 231. There is also an intriguing argument, advanced in Greif, Milgrom, and Weingast, "Coordination", that medieval merchant guilds constituted a commitment device ensuring that rulers guaranteed security for trade; as this model circumscribes its coverage to refer specifically to merchant guilds in the early medieval period, and acknowledges that superior institutions for providing commercial security arose by the sixteenth century at latest, it does not fall within the purview of the present paper, which studies the craft and merchant guilds which survived in most European economies for several centuries after 1500 .
} 
multitude of activities over a long period requires detailed empirical findings. This study presents such findings for a large German industrial region between the late sixteenth and the early nineteenth century. In the 1560 s, country people in the southwest German territory of Württemberg began to weave light worsted cloths (“New Draperies”) for export markets. For 250 years, this "protoindustry" employed thousands of people, was the most important single livelihood in many rural communities, and became the economic mainstay of a region of a thousand square kilometres, oneninth of the land-area of Württemberg. The only other industry approaching it in importance was a linen proto-industry with a similar - guilded - institutional structure. Neither of Württemberg's two main proto-industries was economically vibrant. Instead, they were typical of many proto-industries throughout Europe: after an initial phase of rapid expansion, they grew slowly, required little skill, were technologically backward, and offered most of their practitioners a distinctly meagre living. But the Württemberg worsted industry supported 30-40 per cent of the population in the densest industrial communities for two and a half centuries, and survived in pockets well into the nineteenth century. ${ }^{10}$

Throughout its entire history, the Württemberg worsted industry was guilded. Within two decades of its emergence in the 1560 s, established master weavers were collecting money from house to house and organizing a grass-roots campaign to lobby the government for guild privileges. In 1589 , weavers in the administrative district of Calw got a state charter for a "regional" (rural-urban) guild, followed by weavers in the district of Wildberg in 1597. In 1611 the government issued a national ordinance for weavers' guilds in the six main worsted-producing districts. National guild ordinances were issued in 1654 and 1686, and auxiliary legislation expanded upon them throughout the eighteenth century. Worsted-weaving remained guilded until the abolition of all Württemberg guilds in 1864.

Although making worsteds was early limited to guild masters, trading in them was initially

\footnotetext{
${ }^{10}$ On Württemberg's two proto-industries, see Ogilvie, State Corporatism, ch. 4; Troeltsch,
} 
open to all comers, and included women, peasants, and foreigners - anyone with a bit of capital and time to invest in buying cloths and transporting them to nearby trade fairs. ${ }^{11}$ Thus, for instance, in 1643 Magdalena Frohnmüller, who had lost her weaver husband eight years earlier, was exporting worsteds in bulk to the neighbouring territory of Baden despite the risks of military plundering. ${ }^{12}$ But in 1650, 22 merchants and dyers in the small town of Calw (population c. 2,000) formed a guild-like "association", lobbied the princely bureaucrats, and secured state privileges legally entitling them to exclude all other dyers and exporters of worsteds, and to compel all weavers to sell only to their association, at fixed prices and quotas. This guild-like merchant-dyers' association - the notorious Calwer Zeughandlungskompagnie - astutely used state loans, bribes, and systematic lobbying to expand its economic privileges and its political influence, and was only dissolved when worsted exports collapsed in the late 1790 s. $^{13}$

This institutional pattern was widespread in export-oriented proto-industries outside England and the Netherlands. Guilds were almost universal in the urban finishing stages, such as dyeing. Guild-like merchant "associations" exercising exclusive purchasing and exporting rights were the norm among proto-industrial traders. And in many proto-industries, particularly in central, southern and eastern Europe, rural proto-industrial producers were also guilded - as in Württemberg. ${ }^{14}$ Guilds' widespread survival in export-oriented proto-industry and commerce as well as traditional crafts makes it the more important to investigate their economic impact.

It is therefore fortunate that detailed sources survive, documenting the Württemberg protoindustrial guilds. A unique series of annual account-books survive for the weavers' guild in the most

Zeughandlungskompagnie, chs. 1-4; Medick, Weben.

${ }_{11}$ Troeltsch, Zeughandlungskompagnie, 39-40.

12 HSAS A573 Bü. 128, fol. 82r, 29.8.1643.

${ }^{13}$ Ogilvie, State Corporatism, esp. 89-94; Troeltsch, Zeughandlungskompagnie, esp. 49-69, 80-135.

${ }^{14}$ Ogilvie, State Corporatism, 72-79, 419-37; Reininghaus, Gewerbe, 61-3, 71-72, 79-80; Pfister,

"Craft Guilds", esp. 11-14. 
densely industrial district in the region, Wildberg, covering the period $1598-1760 .{ }^{15}$ The colossal business registers of the Calw merchant-dyers' association also survive for long periods between 1650 and $1797 .{ }^{16}$ The Württemberg "Upper Council” preserved hundreds of metres of petitions, lists, registers, and correspondence relating to the industry, the weavers' guilds, and the merchant-dyers' association. ${ }^{17}$ Local courts kept detailed minutes with many references to local guild activities. ${ }^{18}$ Finally, state ordinances and other administrative decrees defined the legal basis for guilds' privileges and obligations. ${ }^{19}$ This outstanding store of documentation makes it possible to reconstruct the entire array of activities pursued by the weavers' guilds and the merchant-dyers' association on the local level over a period of centuries. What light does it shed on alternative models of guilds?

\section{Did Guilds Correct Market Failures Relating to Product Quality?}

A first "rehabilitation" model argues that guilds arose and survived for so long because they overcame asymmetries of information and problems of delegated monitoring relating to product quality. According to this argument, information asymmetries between producers and consumers were greater in preindustrial than in modern economies. Uncertainty about quality reduced consumers' willingness to purchase, decreasing gains from trade. Guilds are supposed to have corrected this, by regulating raw materials, production processes, apprenticeship, journeymanship, mastership examinations, trademarks, and output quality, and by contracting collectively with merchants. $^{20}$

\footnotetext{
${ }^{15}$ HSAS A573 Bü. 777-911.

${ }_{17}^{16}$ Analyzed in Troeltsch, Zeughandlungskompagnie, 136-89.

${ }^{17}$ HSAS A228, Bü. 256-304.

${ }^{18}$ HSAS A573 Bü. 1-103; PAW KKP, Vols. I-VIII; PAE KKP, Vols. I-VIII.

${ }^{19}$ Printed in Reyscher, Sammlung, vol. 13, 364, 500-01, 615-40; vol. 14, 178; and Troeltsch, Zeughandlungskompagnie, 431-84.

${ }^{20}$ Gustafsson, "Rise", 5, 13-24; Pfister, "Craft Guilds", 14-16.
} 
The evidence adduced in support of this view is of two types. One consists of the frequent references to poor craftsmanship in contemporary plays and poems, which are supposed to show that quality was a serious problem and that guilds existed to control it. ${ }^{21}$ The problem is that literature serves explicitly rhetorical and often normative ends, making it an unreliable guide to what was actually happening. Literary references to poor craftsmanship, for example, may as easily have arisen from guilds' failure to control quality as from their desire to do so.

A second source of evidence that guilds' main purpose was to monitor quality is that, it is claimed, "the majority of the guild statutes are concerned precisely with demands for a sufficiently high quality of product", and guilds imposed "exceedingly harsh sanctions for violating the quality regulations". ${ }^{22}$ Empirically, this is not true. Only 19 per cent of the articles of the $1589 \mathrm{Calw}$ worsted-weavers' guild charter were even remotely concerned with quality control; in 1611 it was 35 per cent, in 1686 , only 12 per cent. ${ }^{23}$ The content of such articles was minimal: at most, they set legal cloth measurements. Nor were sanctions "exceedingly harsh". The penalties named were lenient, normally fines of $15 \underline{\text { Kreuzer}}$, the lowest guild fine ever inflicted, amounting to about two days' average earnings for a weaver in normal times. Only exceptionally poor cloths were to be defaced and the maker fined by the state. Harsh sanctions such as exclusion from the guild or the community never came into question. ${ }^{24}$

Even if guild statutes had focussed mainly on quality issues and had penalized them severely - which they did not - it is important to recognize that legislation, hitherto the mainstay of guild studies, is a deeply questionable source of evidence about what actually occurred. Many regulations primarily served the rhetorical purpose of justifying the guild's existence and hence were not

\footnotetext{
${ }^{21}$ Gustafsson, "Rise", 3, 13-15, 23; Pfister, "Craft Guilds", 16-17.

${ }^{22}$ Gustafsson, "Rise", 9, 13.

${ }^{23}$ Ordinances reprinted in Troeltsch, Zeughandlungskompagnie, 431-53; and Reyscher, Sammlung, vol. 13, 615-40.

${ }^{24}$ Ogilvie, State Corporatism, 345-8.
} 
enforced. Some were enforced but evaded to a greater or lesser extent. And, as we shall see, some regulations that were enforced did not actually appear in the legislation. We therefore need an outside check on guild legislation.

Such an outside check is provided for the Württemberg worsted industry by the guild account-books, the merchant records, and the community court minutes described earlier. The records of the merchant-dyers' association show that "the ordinances' provision that altogether bad wares should be torn up was never carried out". ${ }^{25}$ Guild account-books shows that quality-related offences were penalized with the lowest average fine, 0.36 Gulden, significantly lower than the 0.59 Gulden imposed for non-quality-related offences, and that enforcement of quality regulations declined significantly as a proportion of the guild's overall regulatory activity between the late sixteenth and the late eighteenth century. ${ }^{26}$

Community court minutes show vividly that, in defiance of modern historians' belief that guild trademarks functioned as effective quality guarantees, ${ }^{27}$ contemporaries regarded guild quality standards as inadequate. Merchants and government repeatedly exhorted worsted-weavers in general to work more carefully and guild inspectors in particular to apply higher quality standards. In 1686, a merchant actually travelled up to Wildberg from Calw "to measure the guild sealing-counter which was supposed to be too short", ${ }^{28}$ an exercise which was repeated subsequently by other merchants, ${ }^{29}$ and was ultimately institutionalized into a periodic merchant inspection of all weavers' workshops. ${ }^{30}$ In 1777, worsted-merchants went so far as to complain in the Wildberg community court about the

${ }^{25}$ Troeltsch, Zeughandlungskompagnie, 120 note 1.

${ }^{26}$ See the analysis in Ogilvie, State Corporatism, 329-33, 345-52.

${ }^{27}$ Gustaffson, "Rise", 22.

${ }^{28}$ HSAS A573 Bü. 839 (1685-6), fol. 66.

${ }^{29}$ HSAS A573 Bü. 847 (1693-4), fol. 102v; HSAS A573 Bü. 848 (1694-5), fol. 16r.

${ }^{30}$ Ogilvie, State Corporatism, 194-5. 
"improper way in which the guild sealing-counter is attended to". ${ }^{31}$ Merchants introduced their own quality controls at point of sale, precisely because guild quality controls were inadequate. ${ }^{32}$

Why did the weavers' guilds enforce their quality legislation so minimally? Community court minutes, guild accounts, and merchant business records show why. First, the guild inspectors or "sealers" were subject to strong social pressures from fellow-weavers. One sealer gave utterance to this when he petitioned to be released from his office, "on the grounds that the sealing takes place very badly, and when one says anything about it one incurs great enmity". ${ }^{33}$ Second, the sealers lacked the requisite knowledge for detecting low-quality work. No pretence was made of appointing skilled or experienced masters as sealers. Instead, the office was a sinecure which rotated among masters every two years according to seniority, so every guild member would get a chance to enjoy the sealing fees. ${ }^{34}$ Furthermore, the guild sealers only inspected cloth size, something easily measured by customers. This rendered the guild quality controls irrelevant to questions of asymmetric information. $^{35}$

Even when guild sealers did enforce the regulations, it is not clear that the motive - or the effect - was to benefit consumers. In 1661, for example, Jacob Zeyher complained that "he cannot get along with the guild sealers ... he has to make the cloth 2 ells wide, he sells such cloth in Offenburg, the people want it like that from him, and otherwise he can't sell it, but the sealers will not seal it for him". The Wildberg guild sealers explained that their objection to Zeyher was that "he sells his cloths very cheap, and thereby causes the craft great injury". It is possible, of course, that Zeyher was cheating his customers, and the guild sealers were indeed protecting these consumers and the reputation of Wildberg cloths. But it is also conceivable that Zeyher was speaking the truth when

${ }^{31}$ HSAS A573 Bü. 96, 17.4.1777, unpag.

32 Troeltsch, Zeughandlungskompagnie, 12, 119-20.

33 HSAS A573 Bü. 91, 29.10.1660, fol. 7r.

34 HSAS A573 Bü. 96, 17.4.1777.

${ }^{35}$ Ogilvie, State Corporatism, 348-52; Troeltsch, Zeughandlungskompagnie, 119-20. 
he said "the people want it like that from him": he had certainly been selling these cloths to Offenburg for several years, and even the guild sealers admitted that they were "very cheap". In this case, the guild seal appears to have been used to not so much to protect consumers against poor products as to protect high-cost producers against cheaper and more innovative competitors. ${ }^{36} \mathrm{~A}$ single, monopolistic entity such as a guild might have been better placed than a variegated range of individual producers to guarantee a single, standard quality. But just these characteristics made a guild less able, and probably also less willing, to undertake the market research and the flexible response to changes in demand necessary to deliver the combinations of quality and price desired by a varied and changing population of consumers.

The guilds of the Württemberg worsted proto-industry did not succeed - and seem not even to have tried - to implement their own quality controls effectively. However, the guild structure of the industry did have effects on quality which were unintended and, unfortunately, negative. Guilds inadvertently affected quality in three ways.

First, the weavers' guilds imposed price-ceilings on raw wool. Wool-traders could therefore only stay in business by supplying low-quality wool, since they were forbidden to charge more for better quality. Poor wool was universally recognized as a major cause of the low quality of Württemberg worsteds. ${ }^{37}$

Second, the weavers' guilds and the merchant-dyers' association imposed piece-rate-ceilings on spinning. This had serious effects on the welfare of thousands of unguilded female spinners, who were legally prohibited from engaging in any guilded work, whose productivity in manual labour was low, and who therefore depended heavily on spinning and begging. ${ }^{38}$ But spinning piece-rate ceilings also harmed quality: since spinners were forbidden to charge more for finer work, they span fast,

\footnotetext{
${ }^{36}$ HSAS A573 Bü. 91, 28.10.1661, fol. 6r, 9r.

${ }^{37}$ Ogilvie, State Corporatism, 352-53; Troeltsch, Zeughandlungskompagnie, 97-101, 154-56, 160-67.

${ }^{38}$ For a detailed analysis of these women's economic options, see Ogilvie, A Bitter Living, ch. 6.
} 
producing coarse and irregular yarn. Poor yarn was universally recognized as another cause of the bad quality of Württemberg worsteds. ${ }^{39}$

Third, the guilds and the merchant-dyers' association engaged in monopoly contracting - the so-called "Calwer Moderation", whereby the prices and quantities of worsteds the merchant-dyers bought from the weavers were collectively fixed in periodic negotiations between their respective guilds under state supervision. ${ }^{40}$ The "rehabilitation" literature views such monopoly contracting as a major benefit of guild organization, arguing that it reduced the transaction costs of monitoring quality in a rural industry with dispersed producers. ${ }^{41}$ However, many of the earliest and most successful proto-industries in Europe were located in societies such as the Netherlands and England where neither the proto-industrial merchants nor the proto-industrial producers were organized into guilds: evidently there existed, at least from the late medieval period onward, alternative institutional frameworks which managed to monitor quality successfully. Furthermore, as the Württemberg example shows, monopoly contracting between guilds of merchants and producers could actually have the opposite effect on quality - a negative one. The monopoly contracts between weavers' guilds and merchant-dyers' association contained no quality provisions: they focussed on fixing quotas and prices. No weaver could charge the merchant-dyers' association more for higher quality, and the association had to buy his quota irrespective of quality. This removed incentives for any weaver to weave carefully, since he could not earn more by doing so. Conversely, the merchantdyers' association could not pay one weaver more for better cloth, since this price would then be demanded by the whole guild. Monopoly contracting between weavers' and merchants' guilds thus created a rigid regime of prices and quotas hindering weavers from profiting from better work and merchants from experimenting with new quality/price ratios which might better suit consumer

${ }^{39}$ Troeltsch, Zeughandlungskompagnie, 34-36, 125-31, 165-66, 171; Ogilvie, State Corporatism, 353-6.

${ }^{40}$ Troeltsch, Zeughandlungskompagnie, 80-135. 
demand. $^{42}$

This showed in the quality outcome. The Württemberg worsted industry was thoroughly regulated by guilds of both weavers and merchants. Had guilds' function been to enhance quality, one would expect Württemberg worsteds to have been of unusually high quality. Instead, they compared poorly with worsted proto-industries in Thuringia, France, the Netherlands, and England, where guilds were weak or absent. ${ }^{43}$ One might blame other factors than guilds, were it not for evidence that the Württemberg guilds' price ceilings on wool, rate ceilings on spinning, and monopoly contracting on cloths dampened the incentives of individual spinners, weavers, dyers, and merchants to enhance quality or adjust it flexibly to demand. More generally, the existence - indeed, superiority - of nonguilded proto-industries in societies such as England and the Netherlands which are regarded as the cradle of the "consumer revolution" suggests either that information asymmetries between preindustrial producers and consumers were unimportant, or that alternative institutions (merchant inspections, state regulations) were better at solving them. ${ }^{44}$

\section{Did Guilds Correct Market Failures Relating to Training?}

A second "rehabilitation" theory contends that guilds efficiently overcame market imperfections relating to training. Preindustrial crafts, it is argued, required formal training in sectorspecific skills. But training markets functioned poorly because of opportunistic behaviour and information asymmetries between trainers and trainees, and between trained craftsmen and customers. This led to under-investment in training, scarcity of skilled labour, lower-quality output,

${ }^{41}$ Pfister, "Craft Guilds", 14-16.

${ }^{42}$ For details of these monopoly guild contracts, see Ogilvie, State Corporatism, 355-56; Troeltsch, Zeughandlungskompagnie, 101, 125-31, 165-6.

${ }_{44}$ Ogilvie, State Corporatism, 352-57; Troeltsch, Zeughandlungksompagnie, 35-7, 126-30, 163-6.

${ }^{44}$ As acknowledged in Pfister, "Craft Guilds", 21; Epstein, "Craft Guilds", 686. 
and lost gains from trade. Guilds arose and survived, it is claimed, because they corrected these market imperfections, by implementing rules against opportunistic behaviour by masters and apprentices, imposing apprenticeship entrance requirements which enabled masters to identify good apprentices, issuing apprenticeship certificates which enabled masters to identify good journeymen and journeymen to obtain appropriate employment, and imposing mastership entrance requirements which enabled apprentices to identify skilled trainers and customers to identify skilled producers. ${ }^{45}$

As with quality controls, the main empirical support for this theory is provided by guild legislation, which always made elaborate provisions for apprenticeship, journeymanship, masterpieces, and admission to mastership. But for the reasons already observed, although legislation is the mainstay of guild studies, it is not a reliable guide to what actually happened. Many regulations primarily served the rhetorical purpose of justifying the guild's existence and were either not implemented at all, or were interpreted in ways that suited the interests of certain parties. Guild regulations governing apprenticeship, journeymanship, and mastership did potentially guarantee skilled training, but they also potentially restricted permission to work in the industry. So independent evidence is needed to see how guilds implemented legislation. Such evidence reveals a much more complicated picture.

Counter to the claims of guild ordinances, worsted-weaving - like many other preindustrial crafts and proto-industries - was not highly skilled and did not require prolonged formal training. As early as 1582 , disgruntled guild masters admitted that peasants, men of other crafts, and even women were setting up as worsted-weavers and selling successfully on export markets, "after learning combing and weaving for only a few weeks or months" ${ }^{46}$ Guilds excluded girls from apprenticeship, as was normal throughout Europe. ${ }^{47}$ Despite this, females were explicitly praised for their craft skills,

\footnotetext{
${ }^{45}$ Gustafsson, "Rise”, 21; Epstein, "Craft Guilds”, 687-93; Pfister, “Craft Guilds”, 18.

${ }^{46}$ Troeltsch, Zeughandlungskompagnie, 10-11.

${ }^{47}$ Ogilvie, A Bitter Living, ch. 3; Roper, Holy Household, 44-9; Stuart, Defiled Trades, 213-9;
} 
as in 1751 when an Ebhausen journeyman told a widowed master that a particular girl "would suit him well as a future wife, because she could work very capably at the worsted-weaving craft" ${ }^{48}$ Despite being denied formal apprenticeship because of her female gender, a master's wife was allowed to practise under her husband's guild license, as in 1675 when one weaver's wife admonished an adult stepson about the proper way to stretch a weft, ${ }^{49}$ or in 1686 when another was prosecuted (without her husband) for Sabbath weaving. ${ }^{50}$ Despite receiving no guild training, a master's widow was allowed to continue the craft workshop on her own, irrespective of how short a time she had been married; widows in fact comprised some 17 per cent of practising weavers. ${ }^{51}$

In the low level of skill required, and the non-necessity of formal training, the Württemberg worsted industry was typical of many, perhaps most preindustrial crafts - and certainly typical of a majority of European proto-industries. Indeed, a number of recent studies have concluded that formal guild training was not required by the technologies used in many - perhaps most - preindustrial European crafts. Yet such low-skilled crafts - and, as we saw earlier, many proto-industries - often organized themselves into guilds, evidently for reasons other than the need to provide guarantees of skilled training. ${ }^{52}$

The reason even low-skilled activities such as worsted-weaving organized themselves into guilds was that apprenticeship, journeymanship, and mastership regulations enabled established producers to restrict entry to the industry, thereby protecting themselves from competition. ${ }^{53}$ As a

Hafter, “Underground”, 14-18, 27-32; Rule, "Property”, 107.

${ }^{48}$ PAE KKP Vol. IV, 7.7.1751, fol. 80r.

${ }^{49}$ PAW KKP Vol. IV, fol. 33r-33v, 17.12.1675.

${ }^{50}$ PAW KKP Vol. V, fol. 60r, 4.6.1686.

${ }^{51}$ Ogilvie, A Bitter Living, ch. 5; Ogilvie, State Corporatism, 135.

52 Simon-Muscheid and Jacobsen, "Resümee", 163; Ogilvie, A Bitter Living, ch. 3; Roper, Holy Household, 44-9; Stuart, Defiled Trades, 213-9; Hafter, "Underground", 14-18, 27-32; Rule, "Property", 107; Sonsenscher, Hatters, 35-6.

${ }^{53}$ Rule, "Property", 107; Hafter, "Underground”, 14-18, 27-32; Lourens and Lucassen, "Gilden”, 66-7, 75-9. 
Württemberg legal treatise stated in 1780 ,

Anyone who wants to learn a craft has to possess particular qualities, which are necessary because without them no-one can be accepted as an apprentice and registered with a guild. Among these qualities is: 1) legitimate birth, the cause being that illegitimate birth is a stain [Macula], and this prevents acceptance into a guild; and 2) masculine sex, since no female may properly practise a craft, even if she understands it just as well as a male person. ${ }^{54}$ What mattered was not whether one "understood" the craft but whether one belonged to an identifiable group - females, bastards - which the guild could justify excluding.

In practice, the Württemberg worsted-weavers' guilds - like nearly all other European guilds - used apprenticeship, journeymanship, and mastership regulations to exclude not only women and bastards, but also Jews, Catholics, Calvinists, Roma (“gypsies”), itinerants, serfs, members of "untouchable" occupations, and often anyone who was not the son of a local citizen or an existing master of the guild. In the Württemberg worsted proto-industry, for instance, sons of non-weavers or non-citizens had to pay a punitively high entry fee, much higher than that charged to sons of guild members. Such fees deterred poor applicants such as the non-local non-weaver's son denied permission to marry a weaver's daughter in 1785 because he "was in no sort of position even to raise the citizenship and mastership admission fees". ${ }^{55}$ During the initial worsted boom, entry was more open (though not to women), but after the 1660 s some 90 per cent of new apprentices and masters were sons of local guild members; the others came from rich families and bought their way into the guild. The only way to get around guild restrictions on apprenticeship and mastership was to seek a state dispensation, like the Wildberg pauper who vainly petitioned the prince in 1769 to overturn the weavers' guild's rejection of her son due to the Macula (stain) of his illegitimate birth. ${ }^{56}$ Fewer than

\footnotetext{
${ }^{54}$ Weisser, Recht, $99-100$.

${ }^{55}$ HSAS A573 Bü. 6948, 17.5.1785.

${ }^{56}$ HSAS A573 Bü. 6947, 3.5.1769.
} 
3 per cent of new apprentices and fewer than 1 per cent of new masters in the district of Wildberg between 1598 and 1760 achieved state dispensations from guild admission barriers, and even then usually just a reduction in fees rather than a relaxation of absolute guild preconditions relating to gender, ethnicity, legitimacy, religion, or paternity. ${ }^{57}$

Functioning mainly as barriers to entry, guild apprenticeship, journeymanship, and mastership often failed to guarantee skills. Masters exploited apprentices as cheap sources of agricultural and household labour, leaving them to complain - vainly - about receiving no training. ${ }^{58}$ All apprentice worsted-weavers received certificates after working out their time, without examination. ${ }^{59}$ Journeymen were supposed to be examined, but one journeyman who produced a masterpiece that local gossip described in 1793 as "not masterly, so that it had to be improved by fulling" was "admitted as a master nonetheless". ${ }^{60}$ The guild-like merchant-dyers' association behaved likewise: members' sons were admitted to full membership with little knowledge of the industry. ${ }^{61}$ Perhaps this should not be surprising: as associations of masters, guilds had incentives to certify members' sons without discrimination, and to permit opportunism by masters who could not be bothered to train their apprentices or journeymen.

Further evidence that guilds were unnecessary to ensure craft skills is the proliferation of females and other black-market workers, here as in other European guilded industries, and the huge lobbying expenditures (discussed in the section on "social capital") which the guilds undertook to defend their monopoly over production licences. ${ }^{62}$ Women, Jews, and other excluded groups were perceived by guild masters as serious competitors, despite being visible minorities whom customers

${ }^{57}$ For quantitative analyses, see Ogilvie, State Corporatism, 155-79, Figs. 6.3-6.10.

${ }^{58}$ See, for instance, HSAS A573 Bü. 16, 3.6.1624, fol. 60r; PAW KKP Vol. VIII, 22.6.1798, fol. 94r.

${ }^{59}$ HSAS A573 Bü. 777-911.

${ }^{60}$ HSAS A573 Bü. 100 (1793), fol. 22v-23r.

${ }^{61}$ Troeltsch, Zeughandlungskompagnie, 65-7.

${ }^{62}$ Hafter, "Underground", 16-8, 30-2; Ogilvie, A Bitter Living, ch. 6. 
could easily identify as non-possessors of guild training. Thus in the early $1750 \mathrm{~s}$, the Wildberg worsted-weavers' guild mounted concerted and successful opposition to Juliana Schweickhert, a poor, fifty-year-old spinster doing black-market combing and weaving, jobs officially reserved for guild masters and journeymen. ${ }^{63}$ In 1787 , local prohibitions on dealing with Jews were strengthened after a Wildberg worsted-weaver complained that "through the peddling of the Jews he and other craftsmen are suffering much interference and weakening of their livelihoods" ${ }^{64}$ These complaints can only have been made because the skills of these women and Jews, despite their legal exclusion from guild training, equalled or surpassed those of guild members. Such evidence suggests that it would be inappropriate to view guilds as efficient institutions that were essential for transmitting and guaranteeing craft skills.

\section{Did Guilds Correct Market Failures Relating to Innovation?}

A third approach to rehabilitating guilds argues that they overcame imperfections in markets for technological innovations. Because information is non-excludable and non-rival, its social benefits may exceed its private benefits, leading to sub-optimal provision or diffusion. This makes it hard to devise an efficient institutional framework to encourage technological innovation. ${ }^{65}$ Recently it has been argued that guilds constituted such an institutional framework, by offering monopoly rents to innovators which overcame disincentives to innovation created by non-excludability, compelling journeymen to travel which overcame barriers to diffusion, requiring skilled training which encouraged technological specialization, and promoting spatial clustering which eased technology

\footnotetext{
${ }^{63}$ HSAS A573 Bü. 904 (1752-3), rubric "Strafen”; HSAS A573 Bü. 906 (1754-5), rubric "Strafen”; HSAS A573 Bü. 904 (1752-3), rubric "Strafen”; HSAS A573 Bü. 906, unpag., rubric "Strafen”. ${ }^{64}$ HSAS A573 Bü. 99, fol. 67v, probable date April 1787, \#197 and \#198.

${ }^{65}$ For an excellent discussion, see Dasgupta and David, "Priority", 5-12.
} 
transfer. $^{66}$

No direct empirical evidence has been adduced in support of these hypotheses: they derive their support partly from theoretical reasoning (monopoly rents could in principle have encouraged innovators, travelling journeymen could in principle have spread innovations), and partly from cases in which guilds did not manifest hostility to a particular technological change, which is taken as evidence that guilds actually encouraged innovations in general. ${ }^{67}$

Guilds' attitudes to innovation were certainly more complex than is represented by the traditional view that guilds always opposed the introduction of new techniques. Many industrial innovations were adopted quietly and without detectable resistance by guilds. The broadclothweavers of late-sixteenth-century Württemberg, for instance, did not oppose the innovations involved in shifting to worsteds. Instead, they simply extended their existing guild privileges to cover the new cloths, thereby excluding the peasants, other craftsmen, and women who had started to compete with them. If a new technique or product did not threaten the well-being of established guild masters, they had no incentive to resist it.

But the same guilds could bitterly resist other innovations which they did perceive as threatening their interests. In 1619-21, an Italian merchant who sought to introduce innovative techniques from France and the Netherlands into the primitive Württemberg worsted technology met such vehement opposition from a guild-like association of Calw merchant-dyers and the local weavers' guilds that he departed and refused all invitations to return. ${ }^{68}$ In 1698 , the Württemberg weavers' guilds lobbied against "several members of the Calw merchant-dyers' association who have begun to make new sorts of $\underline{\operatorname{Schlickh}} \underline{\operatorname{Cadi} \beta}$ and to put them out to be woven, which they are not

\footnotetext{
${ }^{66}$ Epstein, "Craft Guilds”, 693-705; Reith, “Technische Innovation”, 43-9.

${ }^{67}$ On this lack of direct evidence, see Reith, "Technische Innovation", 46.

${ }^{68}$ Troeltsch, Zeughandlungskompagnie, 35-8.
} 
entitled to do". ${ }^{69}$ In 1709-10, the weavers' guilds allied with their usual enemy the merchant-dyers' association to lobby (successfully) against a textile manufactory in Stuttgart that sought to produce more advanced worsteds. ${ }^{70}$ In 1775 , the guilds of weavers and merchants again successfully blocked a textile manufactory in Nagold whose "technical advances and new work opportunities" threatened their own industry. ${ }^{71}$ Like most guilds, those in Württemberg tolerated some innovations while blocking others which they perceived as a threat. ${ }^{72}$ What guilds provided was the means - the "social capital" lowering the costs of collective action - which established producers could use to resist innovation when it threatened their interests.

The "rehabilitation" approach acknowledges that guilds often opposed innovations but seeks to explain it away in two ways. First, it argues that modern researchers over-estimate the importance of the innovations opposed by guilds, which were often economically or technological impractical. ${ }^{73}$ But if the technique was no good and would not be adopted anyway, then why oppose it? The very fact that a guild mounted costly opposition to a technique suggests that it did compete with established practices and threaten members' rents.

Second, it is argued that guilds' attempts to block innovation failed: innovations were secretly adopted, innovators forced guilds to liberalize by threatening to emigrate, or other guilds adopted the innovation anyway. But the fact that regulations are evaded does not mean that they have no costs, as analyses of the "informal" sector in modern less-developed economies vividly show. ${ }^{74}$ Concealing forbidden innovations or migrating to a guildless enclave were costly, deterring the

${ }^{69}$ HSAS A573 Bü. 851 (1698-9), fol. 25r-v.

${ }^{70}$ HSAS A573 Bü. 862 (1709-10), fol. 26r-v.

${ }_{71}^{71}$ HSAS A228 Bü. 1698 (1775-7), \#1-58; Troeltsch, Zeughandlungskompagnie, 90-1, 130-1.

72 For other examples, see Thomson, "Proto-industrialization", 88; Ogilvie, State Corporatism, 42431; Pfister, "Craft Guilds", 19-20; Reith, "Technische Innovation”, 39-41, 50-3, 56-7.

${ }_{73}$ Reith, “Technische Innovation", 38-41; Epstein, "Craft Guilds”, 695.

74 Todaro, Economic development, 270-1; Ray, Development economics, 261, 346-8, 395-6; Soto, Other Path. 
marginal innovator. Neither the existence of more liberal regimes nor threats of emigration by individuals inevitably forces inefficient institutions to liberalize. In preindustrial Europe, political coercion, trade protection, market segmentation, transportation costs, and migration restrictions enabled guilds to protect their markets against technologically superior competitors for generations, sometimes for centuries. ${ }^{75}$

The argument that guilds were too weak to hinder innovation is also inconsistent with the argument that they were strong enough to encourage innovation by enforcing training regulations, offering monopoly rents to innovators, requiring journeymen to travel, and promoting spatial clustering. Guilds in the Württemberg worsted industry were certainly strong enough to enforce apprenticeship regulations. But in practice, as shown earlier, these regulations were used not to guarantee skill but to exclude outsiders. The Württemberg guilds were also strong enough to offer monopoly rents, as shown by their successful efforts to restrict entry, impose output quotas, and depress input prices. But these rents went to all masters, irrespective of whether they were innovative. The Württemberg proto-industrial guilds were also strong enough to require journeymen to travel. But it is not clear that guilds were necessary to ensure such migration: young workers were highly mobile even in guildless sectors such as agriculture ${ }^{76}$ and the Netherlands enjoyed legendary labour mobility and technological innovation, while differing from Germany, France, and England in not requiring journeymen to travel. ${ }^{77}$ Furthermore, as one nineteenth-century commentator pointed out, the Württemberg weavers' guilds actually excluded any technological stimulus which journeymen might have brought to the region by prohibiting the settlement of foreign journeymen. ${ }^{78}$ The Württemberg guilds were strong enough that they could control their members without enforcing spatial clustering, since their writ ran in the countryside as well as in the town. But even where

\footnotetext{
${ }^{75}$ See the examples discussed in Ogilvie, State Corporatism, 424-31; Pfister, "Craft Guilds", 19-20.

${ }^{76}$ On the mobility of farm servants and labourers, see Ogilvie, A Bitter Living, esp. ch. 3 and 6.

${ }^{77}$ Lourens and Lucassen, 'Gilden', 73-5, 77, 79.
} 
industries did cluster spatially - e.g., in towns or particular urban neighbourhoods - it is not clear that this was because of guild pressure: industrial agglomeration is widely observed in the absence of guilds for a variety of reasons long recognized by economists. ${ }^{79}$

The strength of guilds in Württemberg proto-industry had a further effect on technological innovation not recognized in either traditional or rehabilitation approaches. In worsted production, innovation mainly consisted in introducing new cloth varieties. The Württemberg weavers' guilds systematically lobbied against extending the merchant-dyers' association's purchasing privilege to new varieties, and individual weavers often refused to produce new kinds of cloth. In turn, the guildlike merchant-dyers' association repeatedly allowed decades to elapse before it agreed to purchase new worsted varieties from the weavers. Its members preferred to invest their monopoly profits in office, political influence, land, colonial imports, conspicuous religious and charitable observance, and leisure, rather than risking them in uncertain industrial innovations. New worsted varieties were swiftly adopted only in the early phase of the industry, before the guild-like merchant-dyers' association was established, and in the later eighteenth century when merchants obtained privileges permitting them a small "manufactory" employing wage-weavers who relinquished their status as independent guild masters and produced according to merchants' precise prescriptions. ${ }^{80}$

Why was there this extraordinary resistance to so many crucial innovations by both weavers' guilds and merchant-dyers' association? It was a rational response to the incentives presented by their guild organization. First, the merchant-dyers' association only wanted new worsted varieties to be produced if they were included in its purchasing privileges; lobbying for new privileges took time and money, and this delayed introduction of new cloth varieties. Second, the weavers' guilds believed (with some justification) that permitting new cloth varieties would simply expand the power of their

\footnotetext{
${ }^{78}$ Troeltsch, Zeughandlungskompagnie, 165-6.

${ }^{79}$ See, for instance, Marshall, Principles, 267-77; Fujita and Thisse, “Agglomeration”, 339-41.

${ }^{80}$ Ogilvie, State Corporatism, 359-60; Troeltsch, Zeughandlungskompagnie, 119, 161-69.
} 
arch-enemy the merchant-dyers' association, which would shift all the risks of introducing the new varieties onto the weavers. Third, new varieties often required better wool or finer spinning, but (as we saw in the preceding section) the weavers' guilds and the dyers' association capped prices of these inputs, depressing their quality; when new cloth varieties were produced, the poor quality of the wool and yarn often meant they failed to sell. Fourth, any change in cloth varieties led to an expensive round of political negotiations between weavers' guilds and merchant-dyers' association. Each party rationally feared being caught on the losing end of this inevitable lobbying struggle, being locked into an inflexible set of obligations which would work to its disadvantage if international prices or demand moved in the wrong direction. The fear of regulatory re-equilibration deterred both guilds from seeking to innovate. ${ }^{81}$ The market interlinkages created by the interlocking privileges of guilds of craftsmen and merchant-dyers thus hindered adoption of new techniques, even without deliberate guild action. ${ }^{82}$

\section{Guilds and Social Capital}

A final rehabilitation approach has been to regard a guild as a "social network", a framework within which a carefully-defined group of individuals transact repeatedly with one another and form multi-stranded relationships, thereby generating "social capital" - a store of common norms, shared information, and the willingness and ability to enforce these norms and take other forms of collective action, thereby benefiting the wider society. ${ }^{83}$ Pre-industrial European guilds are explicitly adduced by political scientists and economists as exemplars of social networks which generated beneficial

${ }^{81}$ Ogilvie, State Corporatism, 359-60; Troeltsch, Zeughandlungskompagnie, 84-6, 119, 142-43, 151 52, 161-69, 189-90.

${ }^{82}$ For examples of how interlinked and imperfect factor markets deter innovation in LDC agriculture, see Ray, Development Economics, 420-78.

${ }^{83}$ Coleman, "Social Capital"; Putnam, Democracy; and, from a rapidly expanding literature, the 
social capital. Thus Robert Putnam argues that since medieval times northern Italy's tightly-knit guilded societies facilitated information transmission, norm enforcement, and collective action, in turn ensuring that government was monitored; governmental and economic failure in southern Italy, he argues, was caused by lack of such urban guild networks. ${ }^{84}$ Likewise, economists working on lessdeveloped and transition economies adduce the preindustrial European guild as an example of a social network generating a beneficial social capital of norms, information, enforcement, and collective action for the economy at large. ${ }^{85}$

James Coleman, the originator of the concept of social capital, defined two criteria which social networks must possess in order to generate social capital: "closure" and "appropriability". ${ }^{86}$ "Closure" means that network membership is clearly defined, so that norm-violating behaviour can be collectively punished and norm-compliant behaviour collectively rewarded. Guilds of craftsmen and merchants in Württemberg, as in most of pre-industrial Europe, clearly defined membership through their careful filtering of admission to apprenticeship, journeymanship, and mastership, and their exclusion of women, Jews, and members of many other identifiable groups, even though these possessed the requisite technical skills. ${ }^{87}$

“Appropriability" means that an organization, "once brought into existence for one set of purposes, can also aid others". ${ }^{88}$ Many social networks, especially those with deep historical roots such as guilds, were not deliberately brought into existence for one set of purposes. But guild members did engage in repeated transactions with one another, encompassing different spheres of activity. Thus members of the Wildberg worsted-weavers' guild transacted in the same factor and product markets, socialized over wine at their regular tavern, collaborated on petitions to the ruler,

essay collection edited by Dasgupta and Serageldin, Social Capital.

${ }^{84}$ Putnam, Democracy, 163-85.

85 Dasgupta, "Economic Progress", 351-2; Raiser, "Informal Institutions", 231.

${ }^{86}$ Coleman, "Social Capital", 23-7.

${ }^{87}$ Ogilvie, State Corporatism, 45-57, 72-9, 127-80. 
marched to Stuttgart to hold political demonstrations, and attended each other's weddings and funerals. These multi-stranded or "multiplex" relationships among guild members allowed, in Coleman's formulation, "the resources of one relationship to be appropriated for use in others", making it more possible to generate social capital.

Guilds, like other social networks, are regarded as generating social capital in four main forms: the fostering of shared norms; the improvement of information flow about these norms; the punishment of violations against these norms; and the organization of collective action in defence of these norms. These manifestations of social capital are held to have benefited not just guild members but the economy at large. ${ }^{89}$

Guilds in preindustrial Württemberg certainly created social capital in the sense that they fostered shared norms. Local documents are replete with explicit statements of such norms. In 1598, for instance, the Wildberg weavers' guild declared explicitly that it was wrong for "absolutely anyone who has not been apprenticed to the craft to practise it, whether in towns or villages". ${ }^{90}$ In 1611 , the weavers' guilds of the entire Württemberg worsted region stated that unmarried females should be forbidden to make wefts, in order that girls "might be kept to other and necessary domestic tasks and business". ${ }^{91}$ In 1623, guild members explicitly declared it to be "dishonourable" for a weaver to pay a spinner above the piece-rate ceiling; one weaver rumoured to have violated this norm had to sue his accusers "in order to rescue his honour". ${ }^{92}$ In 1650, the guild-like merchant-dyers' association justified its monopoly on the grounds that "it is much better and more useful to conduct

${ }^{88}$ Coleman, "Social Capital”, 23-7.

${ }^{89}$ Putnam, Democracy, 163-85; Dasgupta, “Economic Progress”, 351-2; Raiser, “Informal Institutions", 231.

${ }^{90}$ HSAS A573 Bü. 777, unpag., rubric "Zöhrung”.

91 "Engelsattweberordnung" (1611), reprinted in Troeltsch, Zeughandlungskompagnie, 435-53; here article 20, 446.

${ }^{92}$ HSAS A573 Bü. 15, fol. 618r, 20.2.1623. 
trade out of one single hand than out of many unequal and separate hands". ${ }^{93}$ In the 1720 s, the Wildberg weavers' guild fostered a new norm that members must shun the "untouchable" knacker: masters and journeymen were punished for remote contacts such as touching the knacker's horse or sleeping on the knacker's lawn, "thereby shaming the guild". ${ }^{94}$ In the 1780 s, guild masters prevailed on communal authorities to restate the norm "forbidding trade and peddling by Jews outside the public periodic markets, and ... explicitly warning the entire citizenry against it". ${ }^{95}$

But did these norms benefit the wider economy? The norm that it was wrong to practise this low-skilled activity without guild apprenticeship served primarily to exclude entrants regardless of how well they "understood" the craft, as we saw earlier. The norm that women should be limited to housework rather earning income from craft work also served primarily to protect established producers from competition. The norm that it was "dishonourable" to pay spinners a competitive wage made spinning labour scarce, depressed yarn quality, and caused hardship to thousands of women - 15 per cent of spinners were dependent on charity. ${ }^{96}$ The norm that worsted-exporting should be monopolized by a single merchant guild depressed cloth quality, stifled innovation, and harmed weavers and other entrepreneurs. The norm that intercourse with Jews and knackers was "defiling" was economically inefficient and socially divisive. ${ }^{97}$ As James Coleman himself acknowledges, "effective norms in an area can reduce innovativeness in an area, not only deviant actions that harm others but also deviant actions that can benefit everyone". ${ }^{98}$ Guild norms in Württemberg penalized “deviant” actions - occupational mobility, women’s employment,

\footnotetext{
93 “Rezess Zwischen denn Ferbern vnnd der Knapschafft zue Calw vnnd selbiger refier" (2.9.1650), reprinted in Troeltsch, Zeughandlungskompagnie, 453-56.

${ }_{94}$ HSAS A573 Bü. 876 (1723-4), fol. 10v; Ogilvie, State Corporatism, 333-9.

${ }^{95}$ HSAS A573 Bü. 99, fol. 67v, probable date April 1787, \#197 and \#198.

${ }^{96}$ HSAS A573 Bü. 6967 (1736); Ogilvie, A Bitter Living, ch. 6.

${ }^{97}$ On guilds' discrimination against women, Jews, bastards, and members of "dishonourable" occupations, see Roper, Holy Household, 36-55; Ogilvie, State Corporatism, 336-8; Stuart, Defiled Trades, 189-221; Ogilvie, A Bitter Living, ch. 7.
} 
competitive wages, non-monopolistic commerce, and moves to break down gender and racial discrimination - that could have benefited everyone.

This should be borne in mind when we assess the second way in which guilds created social capital, by improving information flow. The weavers' guild had officials in every weaving community who were obliged to report known offences. Together with the merchant-dyers' association, the weavers' guild also employed special "loom-inspectors" who carried out periodic "visitations" of all workshops to check for "forbidden" equipment, excessive apprentice or journeyman numbers, or violations of the output quota. ${ }^{99}$ The guild also paid spies, as in 1707-8 when it employed an Emmingen weaver "who went around in the villages and investigated whether there were any [apprentices who were non-masters' sons] to be found there". ${ }^{100}$ About every seven months, the guild held a general assembly attended by over 95 per cent of the membership. Here, each master in turn was asked if he had anything to report, as in 1752 when several masters were reported by their fellow guild-members for illegally employing a 50-year-old spinster, "to weave and comb, counter to the guild ordinance". ${ }^{101}$ Local communities also held periodic general assemblies, at which each citizen in turn was asked if he had anything to report, as in 1669 when one weaver reported that Hannß Schrotter had been "setting his servant girl behind the loom and having her weave", despite already having been forbidden to do so. ${ }^{102}$

These information-transmission mechanisms did ensure that guild members were aware of each other's activities. But it is clear that they were used for harmful as well as beneficial purposes: to enforce output quotas, prevent adoption of new equipment, limit apprenticeship by nonmasters' sons, and prevent women's work - e.g., to stifle “innovations” that could, in Coleman's

98 Coleman, "Social Capital", 23.

${ }^{99}$ Ogilvie, State Corporatism, 193-7.

${ }^{100 .}$ HSAS A573 Bü 860 (1707-8), fol. 29v.

101 Ogilvie, State Corporatism, 316-21; HSAS A573 Bü. 904 (1752-3), unpag., rubric "Strafen”.

${ }^{102}$ HSAS A573 Bü. 92, fol. 5v, 1.11.1669. 
formulation, have benefited everyone.

The same applies to the third way in which guilds created social capital, by facilitating group action against violations of its norms. The guild was entitled autonomously to punish a vast array of offences, many of them not laid down explicitly in any legislation but simply decided upon at the discretion of the guild officials. The 143 years of surviving guild account-books between 1598 and 1760 show the Wildberg guild imposing fines on 653 individuals for 85 separate types of offence. The minimum fine was two days' average earnings (e.g., for quality offences), the maximum nine days' earnings (e.g., for illegally employing women). ${ }^{103}$ A special range of fines was invented in the early eighteenth century to penalize "defiling" contacts with "untouchable" social groups. ${ }^{104}$ Some offenders, such as the Wildberg master who set his maidservant behind the loom in 1669 , were fined by the state as well. ${ }^{105}$ Weavers who sold to traders outside the privileged merchant-dyers' association were fined and lost their wares, at a minimum cost of one week's earnings; the proceeds were split between guild and state. ${ }^{106}$ Individual weavers perceived guild fines as a deterrent, as in 1623 when Hans Pfeiffer complained that a fellow-weaver, by spreading rumours that he had overpaid a female spinner, "had sought to bring him into punishment before the guild". ${ }^{107}$

But was this social capital of collective sanctions beneficial? It sustained the weavers' monopoly over weaving and the merchant-dyers' monopsony over dyeing and exporting, it helped masters pay non-competitive wages to spinners, it enforced the cartelistic output quotas, and it penalized those who failed to discriminate against females and "defiling" social groups. One must surely question whether this social capital benefited the wider society.

Similar questions arise in evaluating the fourth way in which guilds created social capital, by

${ }_{104}^{103}$ For quantitative analyses of guild fines, see Ogilvie, State Corporatism, 321-39.

${ }^{104}$ Ogilvie, State Corporatism, 333-9.

${ }^{105}$ HSAS A573 Bü. 92, fol. 5v, 1.11.1669.

${ }^{106}$ HSAS A573 Bü 829 (1673-4), fol. 33-4; HSAS A573 Bü 830 (1674-5), fol. 14, 31; HSAS A573 Bü 854 (1700-01), fol. 14v. See the detailed discussion in Ogilvie, State Corporatism, 202-3. 
collectively monitoring the government. The weavers regarded a major reason for the existence of their guild as being to monitor - indeed, lobby - the government to ensure that "appropriate" political decisions were taken. Over the 143 years of surviving accounts between 1598 and 1760, the Wildberg guild spent more than a quarter of its revenues on lobbying, a sum equivalent to 115 days' average earnings for a weaver every year of the guild's existence. ${ }^{108}$ In particularly troubled periods, such as the 1680 s, the Wildberg guild alone was spending on its annual lobbying a sum equivalent to the price of two houses. Individual guild members also invested time in lobbying, most notably in 1689 when one-sixth of the entire guild membership marched to Stuttgart in a body to perform a "Fueß Fall” (literally a "foot fall”) in front of the prince. ${ }^{109}$ These expenditures alone suggest that the guild created economic rents for its members - people do not spend time and money defending valueless privileges. The guild's unremitting series of campaigns to monitor the government ranged from relatively trivial affairs such as a campaign to prevent village schoolmasters from weaving, through serious conflicts such as putting down a journeyman's strike or confiscating black-market yarn from village spinners, to enormous struggles which absorbed the entire financial strength of the guild for years on end, as with the campaigns to obtain more favourable legislation against the merchant-dyers' association in the 1680s and the 1740s. The merchant-dyers' association behaved likewise, astutely securing government support through intermarriage with local officials, bribes to bureaucrats, and massive state loans. These investments paid off, as in 1736 when the state greatly extended the association's privileges, on the grounds that "it was a substantial national treasure, as shown especially with the moneys that had to be raised during the recent French invasion threat, and hence no just opportunity should be lost to extend it a helping hand in all matters". 110

\footnotetext{
${ }^{107}$ HSAS A573 Bü. 15, fol. 618r, 20.2.1623.

${ }^{108}$ See the analysis in Ogilvie, State Corporatism, 366-78, esp. Table 10.1.

${ }^{109}$ HSAS A573 Bü. 842 (1688-9), fols. 94-8, 107-10; described in detail in Ogilvie, State Corporatism, 376-7.

${ }^{110}$ Quoted in Troeltsch, Zeughandlungskompagnie, 84 note 2.
} 
One cannot help but feel some sympathy for the weavers' guilds in their conflicts with the privileged merchant-dyers' association. But the master weavers themselves enjoyed equally oppressive legal privileges over their own journeymen and spinners. Furthermore, guild lobbying by both weavers and merchants consumed vast resources of money and time, and secured public policies that benefited well-organized producer interests at the expense of employees, suppliers, would-be entrants (often, as we have seen, members of the most deprived and excluded sectors of society), and ordinary consumers. In a wider perspective it is not clear that guilds' use of social capital to monitor and influence the political process benefited the economy as a whole.

\section{$\underline{\text { VII. Conclusion }}$}

Using economic theory to understand preindustrial European guilds opens exciting new perspectives, as we shall see shortly. But it is important that our economic models stand up to thorough empirical tests. This paper has sought to confront certain theoretical speculations about the economic effects of guilds with a detailed empirical investigation which encompasses the whole range of guild activities, uses non-legislative sources, and sets guilds in their wider socio-political and technological context.

Its findings suggests serious grounds for scepticism about the hypothesis that guilds arose and survived because they corrected market imperfections. Information asymmetries between producers and purchasers certainly existed, but many important and long-lived guilds - such as those in the Württemberg worsted industry - did not make any contribution to solving them. Imperfections in training markets may also have existed in the preindustrial economy, but the empirical evidence examined in this paper provides reasons for doubting that guilds were an efficient institution for correcting them. Imperfections in markets for innovative techniques exist in all economies, and no 
perfect institution for solving them has yet been devised. But sober empirical investigation suggests little reason to believe that guilds were this institution.

Social networks generating a social capital of shared norms, common information, mutual sanctions, and collective political action may - in some forms - overcome problems posed by lack of trust, reputation, monitoring, and cooperation in developing economies. But the evidence presented in this paper provides greater support for the possibility already acknowledged by James Coleman - that social capital might reduce innovativeness and economic well-being by penalizing "deviant" actions that could have benefited the economy at large. ${ }^{111}$ Despite widespread advocacy of social capital as a cure to all the ills of today's developing economies, almost no theoretical attention has been devoted to analyzing what institutional mechanisms, if any, could be put in place to ensure that social capital is used for beneficial rather than harmful ends. The evidence on preindustrial social capital presented in this paper suggests that such attention is badly needed. In the meantime, we must treat social capital with caution. Most existing studies of social capital assume that its benefits outweigh its costs; this paper suggests that we must question this assumption - and test it empirically.

So how can we use economic theory to help us move forward in this difficult and tangled area? Economics can help us understand why guilds existed in so many societies and sectors, and survived for such long periods of time, without being efficient institutions. Suppose there exists an institution which is not efficient, in the sense that the benefits of abolishing it exceed the costs. Will it automatically break down? No. To see why not, one need only look at the process by which institutions such as guilds change. Typically, these are institutions where the total benefits of abolition are large, but are spread over a large number of people - potential entrants to the industry, employees, consumers. Consequently, for each individual beneficiary, the benefits of abolishing the institution are small and hence that individual has little incentive to incur the costs of political action

\footnotetext{
${ }^{111}$ Coleman, “Social Capital”, 23.
} 
to change the institution. ${ }^{112}$ The total costs of abolition, by contrast, may be relatively small, but be concentrated on a small group - guild masters, princely officials - so among them, the per capita costs of abolition are high. Thus any one individual loser from abolition has a large incentive to incur the costs of political action to maintain the institution. This "logic of collective action", in Mancur Olson's phrase, means that an institution can survive even if the social benefits of abolition exceed the costs. ${ }^{113}$ Economic approaches that do not assume that observed institutions are necessarily efficient open up exciting new perspectives for analysing the complex interactions between individuals, guilds, and political authorities in preindustrial economies.

We cannot, of course, generalize from Württemberg to all other economies with guilds. But Württemberg was probably closer to the norm than more dynamic pre-industrial European economies such as the Netherlands or England, and its low-skilled crafts and industries were typical of the vast majority of the pre-industrial manufacturing sector. ${ }^{114}$ The findings for this economy, where guilds were strong and long-lived, show that guilds could create greater incentives to "seek rents" (to distort markets in order to redistribute resources away from others and toward themselves) than to correct market failures. As shown by the difficult and often painful process of development even in the richest and fastest-growing economies of early modern Europe - the Netherlands and England - the preindustrial economy had plenty of market failures, and these could be very hard to correct. But the even more painful development of economies such as Württemberg suggests that powerful guilds were not the answer to correcting them.

\footnotetext{
112 The institution itself may also ensure that it includes among its benefits most well-off individuals, excluding only those who would not in any case have resources to invest in trying to abolish it.

113 Olson, Logic.

114 Ogilvie, State Corporatism, 398-475.
} 


\section{$\underline{\text { References }}$}

Coleman, James. "Social Capital in the Creation of Human Capital." In Social Capital. A Multifaceted Perspective, edited by Partha Dasgupta and Ismail Serageldin, 13-39.

World Bank: Washington, 2000.

Dasgupta, Partha, and Paul David. "Priority, Secrecy, Patents and the Socio-Economics of Science and Technology." Working Paper Series: High Technology Impact Program. Stanford University, March 1988.

Dasgupta, Partha, and Ismail Serageldin, eds. Social Capital. A Multifaceted Perspective. World Bank: Washington, 2000.

Epstein, S. R. "Craft Guilds, Apprenticeship, and Technological Change in Preindustrial Europe." Journal of Economic History 58 (1998): 684-713.

Fujita, Masahisa, and Jacques-François Thisse. "Economics of Agglomeration.” Journal of Japanese and International Economies, 10 (1996), 339-378.

Greif, Avner, Paul Milgrom, and Barry R. Weingast. "Coordination, Commitment, and Enforcement: The Case of the Merchant Guild." Journal of Political Economy 102 (1994): 745-76.

Gustafsson, Bo. "The Rise and Economic Behaviour of Medieval Craft Guilds." Scandinavian Economic History Review, 35 (1987): 1-40.

Hafter, Daryl M. "Women Who Wove in the Eighteenth-Century Silk Industry of Lyon." In European

Women and Preindustrial Craft, edited by Daryl M. Hafter, 42-64. Bloomington and Indianapolis: Indiana University Press, 1995.

Hafter, Daryl M. "Women in the Underground Business of Eighteenth-Century Lyon.” Enterprise and

Society, 2 (2001): 11-40.

Hauptstaatsarchiv Stuttgart (HSAS).

Irsigler, Franz, "Zur Problematik der Gilde- und Zunftterminologie." In Gilden und Zünfte, edited by Berent Schwineköper, 53-70. Sigmaringen: Jan Thorbecke Verlag, 1985.

Lourens, Piet, and Jan Lucassen, "Gilden und wanderung: die Niederlände.” In Handwerk in Europa vom Spätmittelalter bis zur Frühen Neuzeit, edited by Kurt Schulz and Elisabeth MüllerLuckner, 65-79. Munich: Oldenbourg, 1999.

Marshall, Alfred, Principles of Economics. 8th edition London: Macmillan, 1920; orig. publ. 1890.

Medick, Hans, Weben und Überleben in Laichingen, 1650-1900. Göttingen: Vandenhoek \& Ruprecht, 1996.

Ogilvie, Sheilagh. State Corporatism and Proto-Industry: The Württemberg Black Forest, 1580-1797. Cambridge: Cambridge University Press, 1997.

. A Bitter Living: Women, Markets, and Social Capital in Early Modern Germany.

Oxford: Oxford University Press, 2003.

Olson, Mancur. The Logic of Collective Action. Cambridge, MA: Harvard University Press, 1971.

Pfarrarchiv Ebhausen (PAE), Kirchenkonventsprotokolle (KKP).

Pfarrarchiv Wildberg (PAW), Kirchenkonventsprotokolle (KKP).

Pfister, Ulrich. "Craft Guilds and Proto-industrialization in Europe, 16th to 18th Centuries." In Guilds, Economy and Society, edited by S. R. Epstein, H. G. Haupt, Carlo Poni, and Hugo Soly, 11-24. Sevilla: International Economic History Conference, 1998.

Raiser, Martin, "Informal Institutions, Social Capital and Economic Transition." in Transition and Institutions. The Experience of Gradual and Late Reformers, edited by Giovanni Andrea Cornia and Vladimir Popov, 218-39. Oxford: Oxford University Press, 2001.

Ray, Debraj. Economic Development. Princeton, NJ: Princeton University Press, 1998.

Reininghaus, Wilfried. Gewerbe in der frühen Neuzeit. Munich: Oldenbourg, 1990. 
Reith, Reinhold. "Technische Innovation im Handwerk der frühen Neuzeit? Traditionen, Probleme und Perspektiven der Forschung". in Stadt und Handwerk in Mittelalter und Früher Neuzeit, edited by Karl Heinrich Kaufhold and Wilfried Reininghaus, 21-60. Köln etc.: Böhlau 2000.

Reyscher, August Ludwig. Vollständige, historisch und kritisch bearbeitete Sammlung der württembergische Gesetze, 19 vols. Stuttgart and Tübingen: Cotta, 1828/51.

Roper, Lyndal. The Holy Household: Women and Morals in Reformation Augsburg. Oxford: Clarendon, 1989.

Rule, John. "The Property of Skill in the Period of Manufacture". in The Historical Meanings of Work, edited by Patrick Joyce, 99-118. Cambridge: Cambridge University Press, 1987.

Simon-Muscheid, Katharina, and Gretha Jacobsen, "Resümee.” In "Was nützt die Schusterin dem Schmied?" Frauen und Handwerk vor der Industrialisierung, edited by Katharina SimonMuscheid, 159-65. Frankfurt and New York: Campus, 1998.

Sonenscher, Michael. The Hatters of Eighteenth-Century France. Berkeley: University of California Press, 1987.

Soto, Hernando de. The Other Path: The Invisible Revolution in the Third World. New York: Basic Books, 1989.

Stuart, Kathy. Defiled Trades and Social Outcasts. Honor and Ritual Pollution in Early Modern Germany. Cambridge: Cambridge University Press, 2000.

Thomson, J. K. J., "Proto-Industrialization in Spain". In European Proto-Industrialization, edited by S. C. Ogilvie and M. Cerman, 85-101. Cambridge: Cambridge University Press, 1996.

Todaro, Michael P. Economic Development in the Third World. Harlow: Longman, 1989.

Troeltsch, Walter. Die Calwer Zeughandlungskompagnie und ihre Arbeiter. Jena: Fischer, 1897. 


\section{CESifo Working Paper Series}

(for full list see www.cesifo.de)

752 Edward Castronova, On Virtual Economies, July 2002

753 Rebecca M. Blank, U.S. Welfare Reform: What's Relevant for Europe?, July 2002

754 Ruslan Lukach and Joseph Plasmans, Measuring Knowledge Spillovers Using Patent Citations: Evidence from the Belgian Firm's Data, July 2002

755 Aaron Tornell and Frank Westermann, Boom-Bust Cycles in Middle Income Countries: Facts and Explanation, July 2002

756 Jan K. Brueckner, Internalization of Airport Congestion: A Network Analysis, July 2002

757 Lawrence M. Kahn, The Impact of Wage-Setting Institutions on the Incidence of Public Employment in the OECD: 1960-98, July 2002

758 Sijbren Cnossen, Tax Policy in the European Union, August 2002

759 Chandima Mendis, External Shocks and Banking Crises in Developing Countries: Does the Exchange Rate Regime Matter?, August 2002

760 Bruno S. Frey and Lars P. Feld, Deterrence and Morale in Taxation: An Empirical Analysis, August 2002

761 Lars Calmfors and Åsa Johansson, Nominal Wage Flexibility, Wage Indexation and Monetary Union, August 2002

762 Alexander R. W. Robson and Stergios Skaperdas, Costly Enforcement of Property Rights and the Coase Theorem, August 2002

763 Horst Raff, Preferential Trade Agreements and Tax Competition for Foreign Direct Investment, August 2002

764 Alex Cukierman and V. Anton Muscatelli, Do Central Banks have Precautionary Demands for Expansions and for Price Stability? - Theory and Evidence, August 2002

765 Giovanni Peri, Knowledge Flows and Knowledge Externalities, August 2002

766 Daniel Friedman and Nirvikar Singh, Equilibrium Vengeance, August 2002

767 Sam Bucovetsky and Michael Smart, The Efficiency Consequences of Local Revenue Equalization: Tax Competition and Tax Distortions, August 2002

768 Tapio Palokangas, International Labour Market Regulation and Economic Growth with Creative Destruction, August 2002

769 Rudi Dornbusch, The New International Architecture, September 2002 
770 Hans-Werner Sinn, Weber's Law and the Biological Evolution of Risk Preferences: The Selective Dominance of the Logarithmic Utility Function, September 2002

771 Thomas Mayer, The Macroeconomic Loss Function: A Critical Note, September 2002

772 Seppo Honkapohja and Kaushik Mitra, Learning Stability in Economies with Heterogenous Agents, September 2002

773 David Laidler, Inflation Targets Versus International Monetary Integration - A Canadian Perspective, September 2002

774 Morten I. Lau, Panu Poutvaara, and Andreas Wagener, The Dynamic Cost of the Draft, September 2002

775 Steven Brakman, Harry Garretsen, and Charles van Marrewijk, Locational Competition and Agglomeration: The Role of Government Spending, September 2002

776 Anke S. Kessler and Christoph Lülfesmann, The Theory of Human Capital Revisited: On the Interaction of General and Specific Investments, September 2002

777 Kjell Erik Lommerud, Frode Meland and Lars Sørgard, Unionized Oligopoly, Trade Liberalization and Location Choice, September 2002

778 Antonio Merlo and François Ortalo-Magné, Bargaining over Residential Real Estate: Evidence from England, September 2002

779 Yu-Fu Chen and Michael Funke, Exchange Rate Uncertainty and Labour Market Adjustment under Fixed and Flexible Exchange Rates, September 2002

780 Michael S. Michael, International Migration, Income Taxes and Transfers: A Welfare Analysis, September 2002

781 Clemens Fuest and Alfons Weichenrieder, Tax Competition and Profit Shifting: On the Relationship between Personal and Corporate Tax Rates, October 2002

782 Jan Bouckaert and Hans Degryse, Softening Competition by Enhancing Entry: An Example from the Banking Industry, October 2002

783 Johann K. Brunner and Susanne Pech, Adverse Selection in the Annuity Market with Sequential and Simultaneous Insurance Demand, October 2002

784 Gregory D. Hess and Eduard Pelz, The Economic Welfare Cost of Conflict: An Empirical Assessment, October 2002

785 Jan Erik Askildsen, Uwe Jirjahn, and Stephen C. Smith, Works Councils and Environmental Investment: Theory and Evidence from German Panel Data, October 2002

786 Geir H. Bjønnes, Dagfinn Rime, and Haakon O. Aa. Solheim, Volume and Volatility in the FX-Market: Does it matter who you are?, October 2002 
787 John Evans and John Fingleton, Entry Regulation and the Influence of an Incumbent Special Interest Group, October 2002

788 Wolfgang Ochel, International Comparisons and Transfer of Labour Market Institutions, October 2002

789 B. Gabriela Mundaca, Moral Hazard Effects of Bailing out under Asymmetric Information, October 2002

790 Gene M. Grossman and Edwin L.-C. Lai, International Protection of Intellectual Property, October 2002

791 John Hassler, José V. Rodriguez Mora, Kjetil Storesletten, and Fabrizio Zilibotti, A Positive Theory of Geographic Mobility and Social Insurance, October 2002

792 Paul De Grauwe and Marianna Grimaldi, The Exchange Rate in a Model with Heterogeneous Agents and Transactions Costs, October 2002

793 Guido Friebel and Mariassunta Giannetti, Fighting for Talent: Risk-shifting, Corporate Volatility, and Organizational Change, October 2002

794 Jan Erik Askildsen, Badi H. Baltagi, and Tor Helge Holmås, Will Increased Wages Reduce Shortage of Nurses? A Panel Data Analysis of Nurses’ Labour Supply, October 2002

795 Marko Köthenbürger and Panu Poutvaara, Social Security Reform and Intergenerational Trade: Is there Scope for a Pareto-Improvement?, October 2002

796 Paul De Grauwe and Laura Rinaldi, A Model of the Card Payment System and the Interchange Fee, October 2002

797 Volker Böhm and Tomoo Kikuchi, Dynamics of Endogenous Business Cycles and Exchange Rate Volatility, October 2002

798 Mariam Camarero, Javier Ordóñez, and Cecilio Tamarit, The Euro-Dollar Exchange Rate: Is it Fundamental?, October 2002

799 Misa Tanaka, How Do Bank Capital and Capital Adequacy Regulation Affect the Monetary Transmission Mechanism?, October 2002

800 Jörg Baten and Andrea Wagner, Autarchy, Market Disintegration, and Health: The Mortality and Nutritional Crisis in Nazi Germany, 1933-1937, October 2002

801 Saku Aura, Uncommitted Couples: Some Efficiency and Policy Implications of Marital Bargaining, October 2002

802 Wolfram F. Richter, Delaying Integration of Immigrant Labor for the Purpose of Taxation, October 2002

803 Gil S. Epstein and Shmuel Nitzan, The Politics of Randomness, October 2002 
804 John Hassler and José V. Rodriguez Mora, Should UI Benefits Really Fall over Time?, October 2002

805 Friedrich Breyer and Stefan Felder, The Dead-anyway Effect Revis(it)ed, October 2002

806 Assar Lindbeck and Solveig Wikström, E-exchange and the Boundary between Households and Organizations, November 2002

807 Dieter Bös, Contests Among Bureaucrats, November 2002

808 Steven Brakman, Harry Garretsen, and Marc Schramm, The Strategic Bombing of German Cities during World War II and its Impact on City Growth, November 2002

809 Florian Englmaier and Achim Wambach, Contracts and Inequity Aversion, November 2002

810 Sarbajit Sengupta, Delegating Recruitment under Asymmetric Information, December 2002

811 Rajshri Jayaraman, On the Partial Public Provision of a Private Good, December 2002

812 Stéphanie Stolz, Banking Supervision in Integrated Financial Markets: Implications for the EU, December 2002

813 Christian Keuschnigg, Taxation of a Venture Capitalist with a Portfolio of Firms, December 2002

814 Inés Macho-Stadler and David Pérez-Castrillo, Settlement in Tax Evasion Prosecution, December 2002

815 Rainer Niemann and Dirk Simons, Costs, Benefits, and Tax-induced Distortions of Stock Option Plans, December 2002

816 Jan-Egbert Sturm and Barry Williams, Deregulation, Entry of Foreign Banks and Bank Efficiency in Australia, December 2002

817 V. Anton Muscatelli, Patrizio Tirelli, and Carmine Trecroci, Monetary and Fiscal Policy Interactions over the Cycle: Some Empirical Evidence, December 2002

818 Claude Hillinger, A General Theory of Price and Quantity Aggregation and Welfare Measurement, December 2002

819 Erkki Koskela and Ronnie Schöb, Optimal Capital Taxation in Economies with Unionised and Competitive Labour Markets, December 2002

820 Sheilagh Ogilvie, Guilds, Efficiency, and Social Capital: Evidence from German ProtoIndustry, December 2002 